\title{
KESETIMBANGAN ENERGI TERMAL DAN EFISIENSI TRANSIENT PENGERING ALIRAN ALAMI MEMANFAATKAN KOMBINASI DUA ENERGI
}

\author{
I GUSTI AGUNG KADE SURIADI DAN MADE RICKI MURTI \\ Jurusan Teknik Mesin, Fakultas Teknik Universitas Udayana \\ E-mail: rickimurtibaik@yahoo.co.id
}

\begin{abstract}
ABSTRAK
Energi yang digunakan dalam pengering biasanya hanya menggunakan satu jenis energi. Dalam kasus ini, penelitian ini dilakukan di sistem pengeringan aliran alam dengan menggunakan cerobong. Kombinasi penggunaan energi dari energi solar dan biomas dapat digunakan berkelanjutan atau bergantian tergantung kebutuhan dan lingkungan. Ini diuji lagi menggunakan prototipe pengering dengan menampilkan ukuran temperatur udara masuk dan keluar dalam permukaan biomas, temperatur udara masuk dan keluar di pengumpul solar, temperatur udara masuk dan keluar di ruangan pengering, kadar air di material kering, temperatur di material kering, temperatur permukaan di sisi dalam dan sisi luar dari dinding ruang pengering, dan intensitas radiasi solar. Data yang dikumpulkan berada di antara 30 menit dan melakukan pengumpulan sejumlah data. Selanjutnya tampilan grafis dari keseimbangan energi panas dan efisiensi sistem dibangkan dengan waktu. Hasilnya menunjukkan bahwa: waktu pengeringan sebesar 7,5 jam. Keseimbangan energi panas dibandingkan dengan waktu menghasilkan bahwa peningkatan kehilangan energi mendorong penggunaan sistem pengurang energi.
\end{abstract}

Kata kunci: penggunaan energi kombinasi, kondisi aliran alam, keseimbangan energi panas, efisiensi sistem pengering

\begin{abstract}
The energy used as a dryer is usually only a single type of energy. In this case, study is conducted on the natural flow dryer system by using the chimney. This combination of energy utilization of solar energy and biomass that can be used simultaneously or one turns in accordance with the needs or circumstances. It has been tested against a dryer prototype by performing measurements on the temperature of the inlet air and exit on biomass furnace, the temperature of the inlet air and exit on the solar collector, the temperature of inlet air and exit on the drying chamber, the water content of dried material, the temperature of dried material, the surface temperature of inside and outside of wall on drying chamber, and the intensity of solar radiation. Data were collected at an interval of 30 minutes and do the processing of such data. Next made in a graphical form of thermal energy balance and system efficiency versus the time. Results obtained that: the drying time was 7.5 hours. Thermal energy balance versus the time found that the increase of energy losses lead to useful energy reduction system.
\end{abstract}

Key words: utilization, natural flow condition, the balance of thermal energy, the efficiency of the dryer system

\section{PENDAHULUAN}

Pengeringan adalah suatu proses pembuangan air yang terkandung pada suatu material yang dikeringkan. Pada proses pengeringan perlu adanya fluida udara kering yang mampu menyerap air di dalam material tersebut. Upaya yang dapat dilakukan untuk membuat udara kering adalah dengan melakukan pemanasan terhadap udara tersebut sebelum melintasi material yang dikeringkan. Dengan kondisi udara yang panas dan kering mampu menyerap air yang membasahi meterial tersebut sampai kering dalam waktu yang lebih singkat. Upaya yang dilakukan untuk mendapatkan udara panas dan kering digunakan kombinasi dari dua sumber energi yang berbeda. Pada penelitian ini digunakan energi yang dihasilkan oleh kolektor surya dan energi yang dihasilkan oleh tungku biomassa.

Exell (1991) telah banyak memberikan sumbangan terhadap ilmu pengetahuan dan teknologi pengering. Pada penelitian yang dilakukan telah dilakukan pembuatan kolektor surya untuk hasilhasil pertanian. Pada proses pengeringan terjadi dua proses, yaitu perpindahan panas dan perpindahan massa (Duffie and Beckman, 1996). Masalah utama adalah mengurangi kadar air pada material sampai batas yang diinginkan. Sarma et al. (2002) melakukan 
eksperimen pengering surya untuk buah-buahan dan sayur-sayuran. Hasil penelitian ini adalah bahwa laju pengeringan dengan proses aliran paksa (force flow) lebih tinggi dibandingkan proses aliran alami (natural flow), tetapi biaya operasionalnya lebih tinggi karena dibutuhkan tenaga listrik sebagai penggerak blower untuk mengalirkan udara pengering secara paksa. Sarno dan Sarwono (2004) melakukan pengembangan pengering bawang merah kemudian dijadikan bawang goreng sebagai bumbu instan untuk dipasarkan di Nganjuk. Widodo dan Hendriadi (2004) telah melakukan penelitian pengembangan pengeringan dengan membandingkan kinerja (performansi) pengering jagung tipe bak datar antara model segiempat dan silinder. Dari hasil penelitian didapatkan hasil bahwa pola penurunan kadar air menggunakan model silinder lebih cepat daripada menggunakan model segiempat.

Salwoko dan Junaedi (2004) telah melakukan pengembangan teknologi pengeringan. Dari hasil uji dengan prototipe oven menunjukkan bahwa penggunaan alat oven pada tingkat pemanasan temperatur $50^{\circ} \mathrm{C}$ selama 6 jam sudah mampu memberikan produk tepung jagung dengan kadar air, warna, ukuran butir dan $\mathrm{PH}$ yang telah memenuhi standar perdagangan. Sumarsono (2005) meneliti perilaku kadar air daun nilam menggunakan proses pengeringan rotary dengan tray dryer. Hasil yang didapatkan adalah tray yang berada pada posisi paling bawah menghasilkan laju pengeringan paling cepat. Budiharti et al. (2005) telah melakukan usaha perbaikan kinerja pengeringan dengan pengering tipe semprot pada lidah buaya melalui modifikasi sistem penyaluran bahan, pemanas dan penyaluran produk.

\section{METODE}

Perpindahan panas konduksi adalah perpindahan energi panas yang terjadi di dalam media padat atau fluida yang diam sebagai akibat dari perbedaan temperatur. Hal ini merupakan perpindahan energi dari partikel yang lebih energetik ke partikel yang kurang energetik pada benda akibat interaksi antar partikel-partikel. Persamaan untuk menghitung laju konduksi dikenal dengan hukum Fourier sebagai berikut:

$q_{\mathrm{konv}}=-k A(d T / d x)$

di mana:

$k=$ konduktivitas termal bahan (W/m.K),

$d T=$ beda temperatur antara permukaan $(\mathrm{K})$,

$d x=$ jarak perpindahan panas $(\mathrm{m})$,
$A=$ luasan permukaan tegak lurus $\left(\mathrm{m}^{2}\right)$, dan tanda minus (-) menyatakan bahwa perpindahan panas terjadi dari temperatur tinggi menuju temperatur rendah.

Perpindahan panas konveksi adalah suatu perpindahan panas yang terjadi antara suatu permukaan benda padat dan fluida yang mengalir akibat adanya perbedaan temperatur. Persamaan untuk menghitung laju perpindahan panas konveksi dikenal dengan hukum pendinginan Newton (Newton's law of cooling) yang dirumuskan sebagai berikut:

$q_{\mathrm{konv}}=-h A\left(T_{\mathrm{s}}-T_{\infty}\right)$

di mana:

$h=$ koefisien konveksi $\left(\mathrm{W} / \mathrm{m}^{2} \mathrm{~K}\right)$,

$A=$ luasan permukaan perpindahan panas $\left(\mathrm{m}^{2}\right)$,

$\mathrm{T}_{\mathrm{s}}=$ temperatur permukaan benda padat $(\mathrm{K})$,

$T_{\infty}=$ temperatur fluida yang mengalir $(\mathrm{K})$.

Perpindahan panas radiasi adalah suatu perpindahan panas yang terjadi secara pancaran gelombang elektromagnetik dari suatu permukaan benda. Laju perpindahan panas radiasi netto dapat dihitung dengan persamaan sebagai berikut:

$q_{\text {Radiasi }}=\varepsilon \cdot \sigma \cdot A\left(\mathrm{~T}_{\mathrm{s}}^{4}-\mathrm{T}_{\text {surr }}^{4}\right)$.

di mana:

$\sigma=$ konstanta Stefan-Bolzmann 5,67.10-8 $\left(\mathrm{W} / \mathrm{m}^{2} \mathrm{~K}^{4}\right)$,

$\varepsilon=$ emisivitas permukaan media, $A=$ luas permukaan perpindahan panas $\left(\mathrm{m}^{2}\right)$,

$\mathrm{T}_{\mathrm{S}}=$ temperatur permukaan benda padat $(\mathrm{K})$,

$\mathrm{T}_{\text {Surr }}=$ temperatur surrounding $(\mathrm{K})$.

Perpindahan massa didefinisikan sebagai perpindahan massa pada suatu media yang diakibatkan oleh adanya perbedaan konsentrasi molar suatu spesies pada media tersebut. Perpindahan massa konveksi dari suatu permukaan material menuju udara pengering dapat dirumuskan sebagai berikut:

$N_{a}=h_{m} A\left(C_{a s}-C_{\infty}\right)$ $(\mathrm{kmol} / \mathrm{s})$

di mana:

$h_{m}=$ koefisien perpidahan massa konveksi $(\mathrm{m} / \mathrm{s})$,

$A=$ luasan permukaan perpindahan massa $\left(\mathrm{m}^{2}\right)$,

$C_{A S}=$ konsentrasi molar spesies dipermukaan benda padat $\left(\mathrm{kmol} / \mathrm{m}^{3}\right)$,

$C_{A \infty}=$ konsentrasi molar spesies pada fluida yang mengalir $\left(\mathrm{kmol} / \mathrm{m}^{3}\right)$. 
Duffie dan Backman (1996) menyatakan performansi sistem pengeringan adalah laju pengeringan yang merupakan penurunan kadar air terhadap waktu, dirumuskan sebagai $M_{w}=M_{w} / d t$ $(\mathrm{kg} / \mathrm{s})$.

Laju energi panas berguna yaitu jumlah energi kalor yang dipergunakan untuk menguapkan massa air pada material persatuan waktu, dinyatakan dalam bentuk persamaan sebagai berikut:

$q_{u}=q_{\text {evap }}=M_{w} \cdot L_{h}$

di mana $\mathrm{L}_{\mathrm{h}}$ adalah panas laten penguapan $(\mathrm{kJ} / \mathrm{kg})$.

Laju energi panas yang memasuki ruang pengering yaitu terdiri dari energi yang dihasilkan kolektor surya dan tungku biomassa dirumuskan:

$q_{\text {in }}=m_{1} \cdot C_{P 1} T_{1}+m_{2} \cdot C_{P 2} T_{2}$

Effisiensi kolektor yaitu perbandingan antara energi udara panas yang dihasilkan oleh kolektor dengan panas masuk kolektor yang dirumuskan

$\eta_{K}=\left(q_{U k o l} / q_{\text {In kol }}\right) \times 100 \%$

Effisiensi tungku biomassa yaitu perbandingan antara energi udara panas yang dihasilkan oleh tungku dengan panas pembakaran biomassa berupa LHV (Low Heating Value) yang dirumuskan sebagai

$\eta_{T B}=\left(q_{T B} / m . L H V\right) \times 100 \%$

Effisiensi pengeringan yaitu perbandingan antara energi panas berguna (energi penguapan) dengan energi panas yang memasuki ruang pengering (energi kolektor + energi tungku biomassa) yang dirumuskan sebagai

$\eta_{p}=q_{\text {use }} /\left(\mathrm{q}_{\mathrm{U} \text { kol }}+q_{T B}\right) \times 100 \%$

Effisiensi termal total sistem pengeringan yaitu perbandingan antara energi panas berguna dengan laju energi panas yang memasuki kolektor surya ditambah energi yang masuk tungku biomassa yang dirumuskan sebagai

$\eta_{T}=\left[q_{\text {use }} /\left(\mathrm{q}_{\text {In kol }}+m . L H V\right)\right] \times 100 \%$

Nilai kalor bahan bakar biomassa didefinisikan sebagai energi panas yang dilepaskan pada saat oksidasi unsur-unsur kimia yang terdapat pada bahan bakar. Panas pembakaran dari suatu bahan bakar adalah panas yang dihasilkan dari pembakaran sempurna bahan bakar pada volume konstan. Panas pembakaran dari bahan bakar dapat dinyatakan dalam Higher Heating Value (HHV) dan Lower Heating Value (LHV). HHV adalah nilai panas pembakaran dari bahan bakar yang di dalamnya masih termasuk panas laten dari uap air hasil pembakaran. Nilai panas dari unsur karbon, hidrogen, dan sulfur dinyatakan dengan persamaan sebagai

$\mathrm{HHV}=33950 \mathrm{C}+144200\left(\left(\mathrm{H}_{2}-\mathrm{O}_{2}\right) / 8\right)+9400$ $\mathrm{S}$ dalam satuan $(\mathrm{kJ} / \mathrm{kg})$

Atau

$\mathrm{HHV}=14544 \mathrm{C}+62028\left(\left(\mathrm{H}_{2}-\mathrm{O}_{2}\right) / 8\right)+4050 \mathrm{~S}$ dalam satuan $(\mathrm{Btu} / \mathrm{lb})$

LHV merupakan panas pembakaran bahan bakar setelah dikurangi panas laten dari uap hasil pembakaran, sehingga

$\mathrm{LHV}=\mathrm{HHV}-\mathrm{L}_{\mathrm{h}} \cdot \mathrm{H}_{2} \mathrm{O}(\mathrm{kcal} / \mathrm{kg})$

atau dapat ditulis sebagai

$$
\mathrm{LHV}=\mathrm{HHV}-92,7 \cdot(\text { total hydrogen })
$$

di mana

$L_{h}=$ panas laten penguapan $\mathrm{H}_{2} \mathrm{O}=600 \mathrm{kcal} / \mathrm{kg}$ $\mathrm{H}_{2} \mathrm{O}=2400 \mathrm{~kJ} / \mathrm{kg} \mathrm{H}_{2} \mathrm{O}$

Kesetimbangan energi termal dapat dijelaskan sebagai berikut: sebuah sistem pengeringan akan selalu memiliki kesetimbangan energi termal, tentunya kesetimbangan tersebut terhadap waktu artinya kesetimbangan energi termal selalu berubah-ubah terhadap waktu. Variabel-variabel kesetimbangan energi termal terdiri dari beberapa jenis, yaitu laju energi masuk sistem pengeringan, laju energi keluar sistem pengeringan, laju energi berguna sistem, laju perubahan energi tersimpan sistem pengeringan. Pernyataan tersebut diterjemahkan dalam bentuk persamaan umum energi termal yang menyatakan bahwa laju energi masuk sistem dikurangi laju energi keluar sistem ditambah dengan laju energi yang dibangkitkan ke dalam sistem adalah sama dengan laju perubahan energi tersimpan di dalam sistem. Hal tersebut dapat dirumuskan sebagai $\dot{E}_{I N}-\dot{E}_{\mathrm{OUT}}+\dot{E}_{\mathrm{GEN}}=\dot{E}_{\mathrm{ST}}$ di dalam sistem pengeringan persamaan umum kesetimbangan energi termal persamaan mengalami perubahan karena $\left(\dot{E}_{\mathrm{GEN}}=0\right)$ sehingga persamaannya berkurang menjadi $\dot{E}_{I N}-\dot{E}_{\text {OUT }}=\dot{E}_{\mathrm{ST}}$ kemudian energi keluar sistem pecah menjadi dua kelompok energi sehingga kesetimbangan energi termalnya menjadi laju energi masuk sistem dikurangi laju energi losses total sistem dikurangi laju energi berguna adalah sama dengan 
laju perubahan energi tersimpan di dalam sistem. Dengan demikian, persamaan kesetimbangan energi termal pada sistem pengeringan adalah:

$\dot{E}_{\text {in }}-\dot{E}_{\text {Losses Total Sistem }}-\dot{E}_{\text {Berguna }}=\dot{E}_{\mathrm{ST}}$

Cepat atau lambatnya proses pengeringan sangat tergantung pada energi dan laju aliran massa udara pengering yang diberikan kepada sistem pengering tersebut sehingga pada penelitian ini dilakukan pengujian pada sebuah prototipe pengering dengan menggunakan kombinasi dua energi, yaitu energi surya dan energi biomassa. Digunakannya proses aliran alami yang memanfaatkan cerobong sebagai pengalir udara pengering adalah dimaksudkan untuk ekonomisasi terhadap proses operasionalnya.

Sumardi et al. (2006) melakukan pengujian pengering energi surya tipe MD-K3 untuk pengeringan kerupuk. Setelah diuji didapatkan hasil yaitu efisiensi pengeringan berkisar antara 13,13-21,20\%. Pada penelitian ini digunakan ketinggian puncak cerobong sebesar $4 \mathrm{~m}$ untuk mengalirkan udara pengering melintasi material yang dikeringkan. Pengujian ini membahas tentang kesetimbangan energi termal (termal energy balance) sistem pengeringan, yang meliputi laju energi masuk sistem pengeringan, laju energi yang berguna sistem pengeringan, laju energi losses sistem pengeringan, dan laju perubahan energi tersimpan di dalam sistem pengeringan. Kemudian juga tentang efisiensi sistem pengeringan, yang meliputi efisiensi kolektor surya, efisiensi tungku biomassa, efisiensi pengeringan, dan efisiensi total sistem pengeringan.

Telah dilakukan pengujian pada prototipe pengeringan dan telah dilakukan pengambilan data tiap-tiap selang waktu 30 menit melalui pengukuran pada variabel-variabel yang meliputi: temperatur udara saluran masuk tungku biomassa, temperatur udara saluran keluar dari tungku biomassa, temperatur udara saluran masuk kolektor surya, temperatur udara saluran keluar kolektor surya, temperatur udara masuk ke ruang pengering, temperatur udara keluar dari ruang pengering, temperatur permukaan bagian dalam dinding ruang pengering, temperatur permukaan bagian luar dinding ruang pengering, temperatur material yang dikeringkan, kadar air material yang dikeringkan, dan Intensitas radiasi matahari.

Setelah didapatkan data dari pengujian, maka dilakukan perhitungan/pengolahan terhadap data selanjutnya sampai didapatkan hasil berupa variabelvariabel kesetimbangan energi termal terhadap waktu dan efisiensi termal sistem terhadap waktu.

Variabel yang dibahas pada kesetimbangan energi termal (termal energy balance) sistem pengeringan

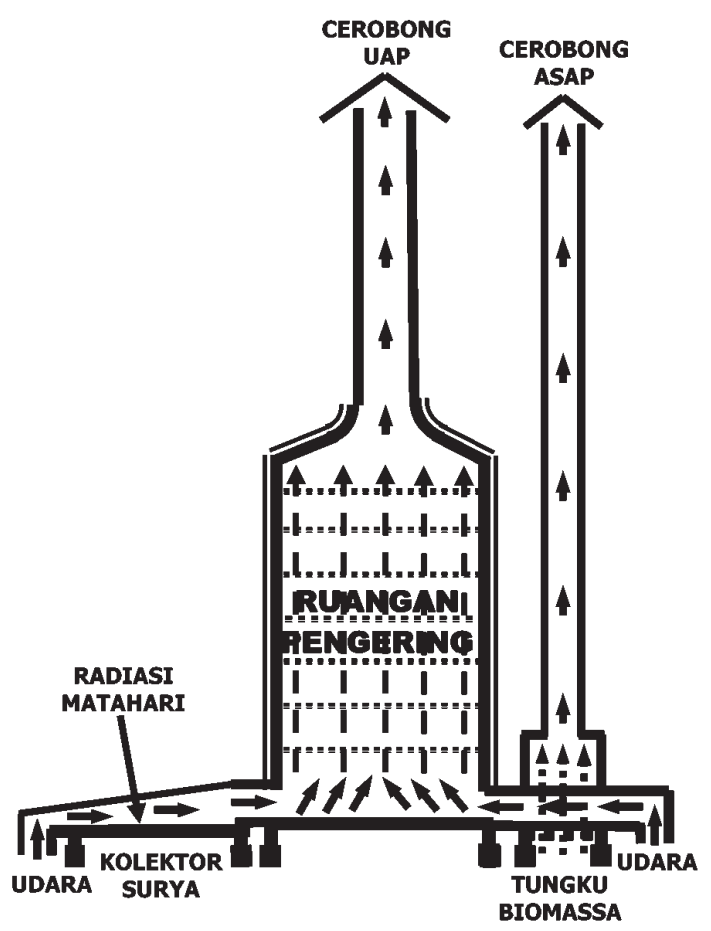

Gambar 1. Skematik Prototipe Sistem Pengering Aliran Alami Energi Kombinasi

meliputi laju energi masuk sistem pengeringan, laju energi yang berguna sistem pengeringan, laju energi losses sistem pengeringan, dan laju perubahan energi tersimpan di dalam sistem pengeringan.

Sedangkan variabel yang dibahas pada efisiensi sistem pengeringan meliputi efisiensi kolektor surya, efisiensi tungku biomassa, efisiensi pengeringan, dan efisiensi total sistem pengeringan. Semua variabel tersebut dibahas secara transient (pembahasannya terhadap waktu).

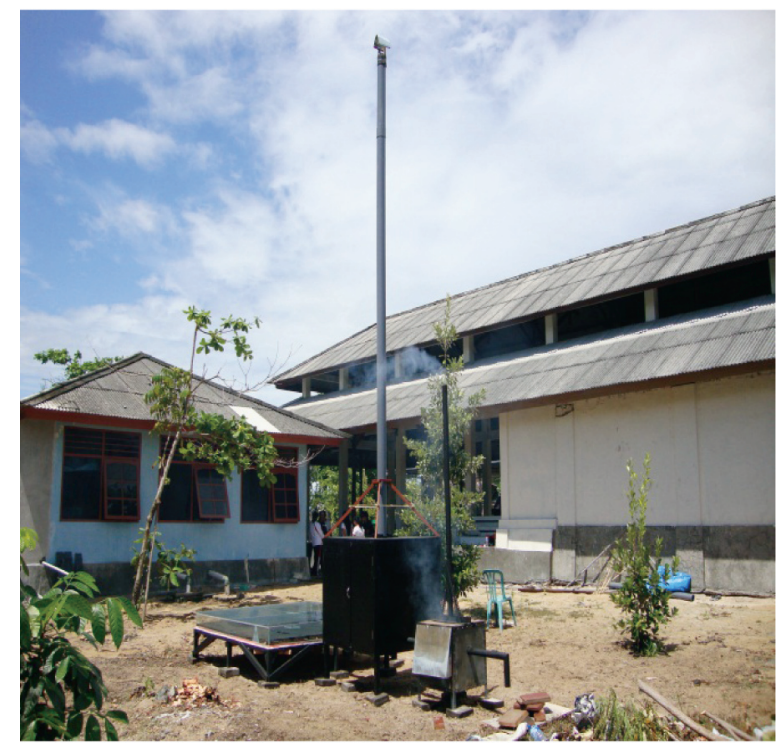

Gambar 2. Prototipe Pengering yang Telah Diuji. 


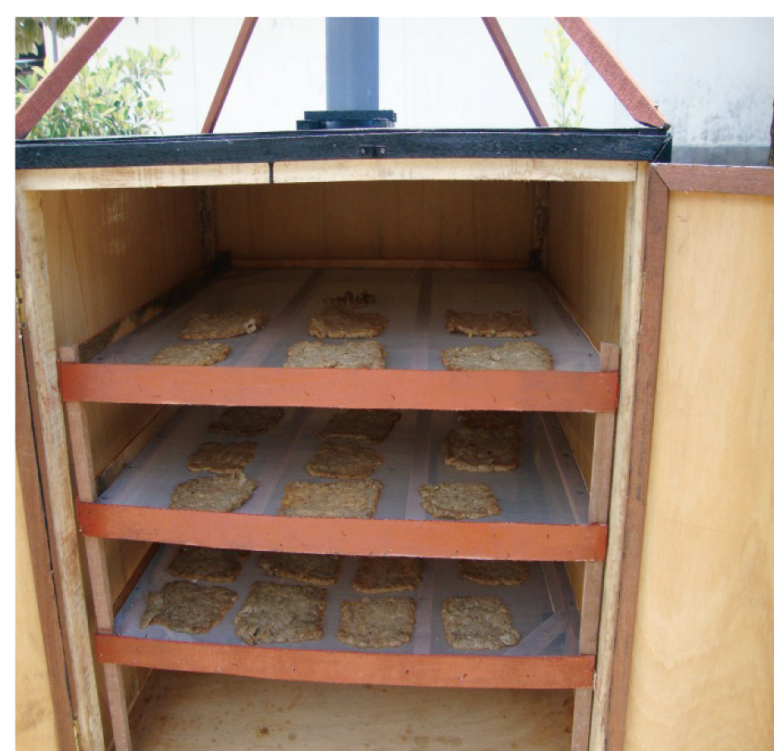

Gambar 3. Proses Produksi Ikan Olahan saat Pengujian Prototipe

Selanjutnya hasil berupa variabel kesetimbangan energi termal sistem pengeringan dan efisiensi termal sistem pengeringan tersebut dituangkan dalam suatu bentuk grafik kesetimbangan energi termal sistem pengeringan terhadap waktu dan grafik efisiensi termal sistem pengeringan terhadap waktu. Pembahasan berupa analisis grafik di mana mengacu pada perilaku kurva masing-masing.

Prototipe pengering yang diuji meliputi seperti yang terlihat Gambar 1 yaitu skematik sistem pengeringan ikan aliran alami kombinasi energi kolektor surya dan tungku biomassa, Gambar 2 adalah prototipe pengering yang telah diuji, dan Gambar 3 adalah proses produksi ikan olahan saat pengujian prototipe pengering.

\section{HASIL DAN PEMBAHASAN}

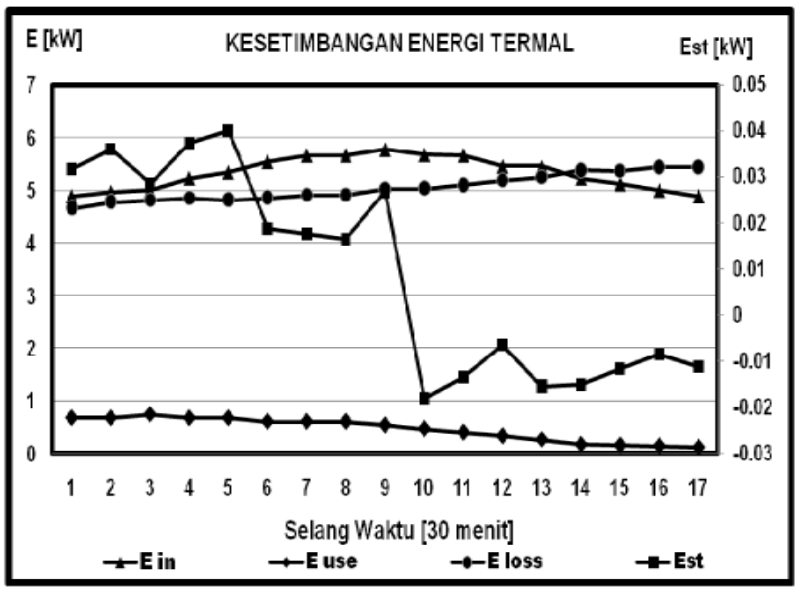

Gambar 4. Grafik Kesetimbangan Energi Termal Sistem terhadap Waktu
Pada grafik kesetimbangan energi termal terhadap waktu yang disajikan pada Gambar 4 terlihat bahwa dari saat selang waktu awal sampai akhir adalah senantiasa dalam keadaan setimbang. Laju energi yang masuk ke dalam sistem yang terdiri dari penjumlahan antara energi panas dari kolektor dan energi panas dari tungku biomassa, terlihat pada kurva yang senantiasa mengikuti kondisi energi yang dihasilkan oleh kolektor surya berarti laju energi masuk sistem dalam keadaan sedikit melengkung. Hal tersebut disebabkan oleh ketergantungannya pada keberadaan intesitas matahari yaitu mengalami peningkatan menuju siang hari dan selanjutnya mengalami penurunan menuju sore hari. Sedangkan energi biomassa bisa dijaga konstan dengan menjaga kondisi massa bahan bakar biomassa dengan nyalanya maupun dengan baranya. Dengan demikian, kondisi energi biomassa menjadi agak konstan. Tetapi setelah digabungkan dengan energi kolektor sebagai energi masuk sistem $\left(\mathbf{Q}_{\text {in }}\right)$, maka kondisinya menjadi sedikit berubah. Terjadi perubahan di mana kelengkungannya mengalami perubahan gradien sehingga kurva energi masuk sistem $\left(\mathrm{Q}_{\text {in }}\right)$ dalam keadaan melengkung dengan gradien lebih kecil.

Energi berguna sistem sangat tergantung pada penguapan air yang terjadi pada material sehingga energi berguna sistem adalah berupa energi panas laten yaitu energi yang berfungsi merubah phase dari cair menjadi uap. Keberadaan penguapan air pada material semakin menurun terhadap waktu karena kandungan air pada material semakin menurun sehingga dapat dikatakan bahwa laju perpindahan massa air dari material menuju ke udara pengering adalah menurun. Dengan menurunnya kandungan air pada material, maka energi berguna pun mengalami penurunan seiring dengan penurunan laju perpindahan massa pada material yang dikeringkan.

Energi losses sistem pengeringan biasanya mempunyai keterkaitan dengan energi berguna. Energi berguna mengalami penurunan berarti energi losses sistem pengeringan mengalami peningkatan. Hal tersebut tidak dapat dihindari dalam suatu sistem pengeringan dan hal tersebut merupakan penyebab utama menurunnya efisiensi sistem pengeringan dan efisiensi total sistem pengeringan terhadap waktu.

Dari grafik pada Gambar 5 terlihat bahwa efisiensi total sistem pengeringan mengalami penurunan terhadap waktu, di mana efisiensi sistem pengeringan merupakan fungsi dari energi berguna sistem. Energi berguna pada sistem pengeringan selalu mengalami penurunan terhadap waktu sebab energi berguna merupakan fungsi dari penurunan kadar air pada material. Penurunan kadar air pada 


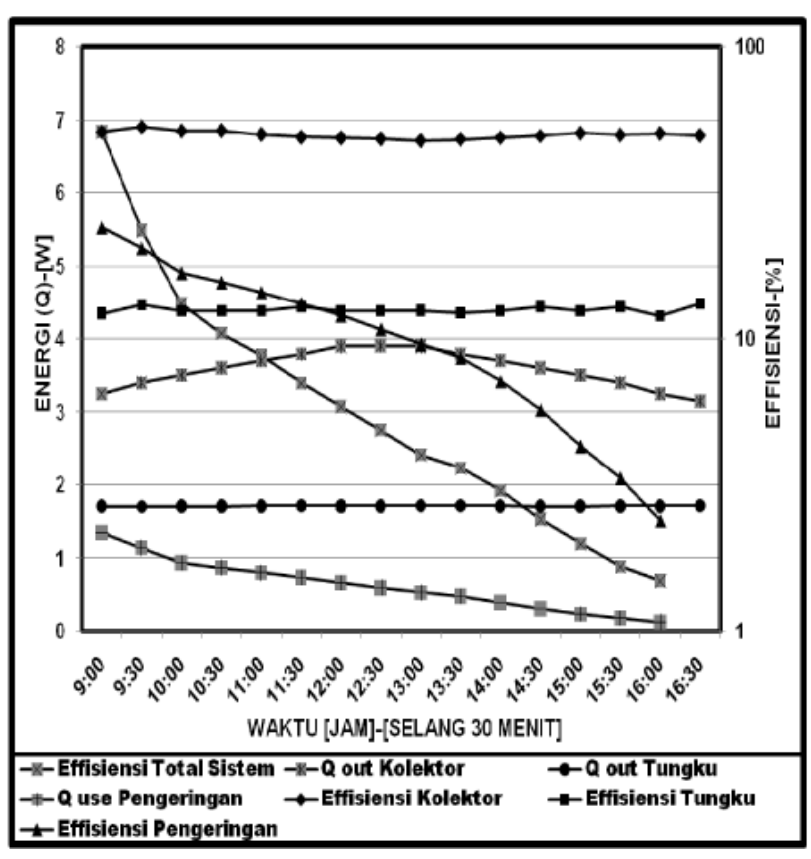

Gambar 5. Grafik Efisiensi Sistem terhadap Waktu

material mengalami penurunan terhadap waktu dikarenakan kandungan air pada material semakin menurun terhadap waktu, dengan demikian proses penguapan (perpindahan massa) air menjadi semakin kecil terhadap waktu.

Energi berguna merupakan fungsi dari panas latent penguapan air pada material sehingga dengan adanya penurunan penguapan air pada material maka kondisi energi berguna mengalami penurunan, walaupun energi masuk sistem pengeringan tidak mengalami penurunan(konstan).

Energi yang mampu dihasilkan oleh tungku biomassa berupa udara panas yang disuplai ke ruang pengeringan adalah lebih kecil dibandingkan dari kolektor surya, karena luas permukaan perpindahan panas sangat kecil sehingga laju perpindahan panas yang terjadi sangat kecil. Jadi pada tungku biomassa terjadi losses yang sangat besar sehingga perlu diminimalis lagi. Dengan kecilnya energi panas (energi berguna tungku biomassa) pada fluida (udara) yang mengalir menuju ruang pengering, maka berarti berdampak pada efisiensi tungku biomassa. Efisiensi tungku biomassa sangat kecil berarti terjadi losses yang sangat besar, yaitu losses panas yang terbuang bersamaan dengan gas buang pembakaran.

Energi udara panas yang dihasilkan oleh kolektor surya adalah lebih besar dibandingkan dengan tungku biomassa karena luas kolektor relatif besar yaitu $4 \mathrm{~m}^{2}$. Radiasi yang mampu menembus kaca penutup kolektor terserap dengan baik dan yang terpantulkan menjadi terhalangi oleh kaca penutup sehingga radiasi seolah-olah terjebak dalam sistem kolektor ini. Dengan kecilnya losses yang terjadi pada sistem kolektor mengakibatkan efisiensi kolektor surya menjadi lumayan besar. Walaupun efisiensi kolektor merupakan perbandingan antara energi berguna kolektor dengan laju intensitas radiasi matahari, tidak berarti dengan menurunnya intensitas mengakibatkan menurunnya efisiensi kolektor. Oleh karena itu, efisiensi kolektor tidak mengalami penurunan dengan menurunnya intensitas matahari.

Efisiensi pengeringan selalu mempengaruhi efisiensi total sistem pengeringan karena efisiensi pengeringan dan efisiensi total sistem pengeringan menggunakan energi berguna yang sama, yaitu berupa energi panas laten pada penguapan air pada material yang dikeringkan. Efisiensi pengeringan selalu lebih besar dibandingkan dengan efisiensi total sistem pengeringan. Efisiensi total sistem sangat kecil, karena merupakan perkalian antara efisiensi dari sub-sub sistem yang merupakan bilangan pecahan berharga di bawah satu sehingga hasil perkaliannya menjadi lebih kecil.

\section{SIMPULAN}

Dari kesetimbangan energi termal didapatkan suatu variabel yang terbalik antara energi berguna sistem pengeringan dengan energi losses sistem pengeringan. Makin kecil energi berguna sistem pengeringan maka energi losses sistem pengeringan meningkat. Efisiensi sistem pengeringan mengalami penurunan terhadap waktu. Begitu juga halnya dengan efisiensi total sistem pengeringan juga mengalami penurunan terhadap waktu. Efisiensi sistem pengeringan dan efisiensi total sistem pengeringan tergantung pada energi berguna. Efisiensi tungku biomassa lebih kecil dibandingkan efisiensi kolektor surya di mana terjadi losses energi panas yang terbuang bersama-sama dengan gas buang hasil pembakaran.

\section{DAFTAR PUSTAKA}

Budiharti, U. et al. 2005. Perbaikan Kinerja Mesin Pengering Semprot untuk Lidah Buaya. Jurnal Enjiniring Pertanian, Balai Besar Pengembangan Mekanisasi Pertanian.

Duffie, J.A. dan Beckman, W.A. 1996. Solar Engineering and Thermal Processes, John Wiley \& Sons, fourth Edition.

Exell, R.H.B. 1991. Basic Design Theory for Solar Dryer, Renewable Energy Review. Journal, Vol. 5, No. 1.

Fiqueiredo, A.R dan Fohr, J.P. 2004. Agricultural Solar Air Collector Design and Performance. The Journal of Solar Energy Science and Technology, Vol. 38, No. 5 hal 50-57. 
Salwoko, S dan Junaedi, M. 2004. Pengembangan Teknologi Pengeringan dan Penepungan jagung. Jurnal Himpunan Politeknik Negeri Indonesia, Vol. III, No. 1 hal 32-40.

Sarno, R. dan Sarwono. 2004. Pengembangan Alat Pengering Bawang Merah dan Produk Olahan (Bawang Merah Goreng dan Bumbu Instan) serta Pemasarannya di Kabupaten Nganjuk. Jurnal Saint dan Teknologi BPPT. Pustaka Iptek.

Sharma, V. K. et al. 2002. Experimental Investigation of Different Solar Dryer Suitable for Fruit and Vegetable. The Journal of Solar Energy Science and Technology, Vol. 6, No. 4.
Sumardi, HS et al. 2006. Uji Performansi Alat Pengering Energi Surya Tipe MD-K3 pada Pengeringan Krupuk. Jurnal Teknik Fakultas Teknik Universitas Brawijaya, April.

Sumarsono. 2005. Perilaku Kadar Air Daun Nilam Hasil Pengeringan secara Rotasi dengan Tray Dryer. Jurnal Ilmu-Ilmu Pertanian Indonesia, Vol 7, No. 1, hal 59-67.

Widodo, P dan Hendriadi, A. 2004. Perbandingan Kinerja Mesin Pengering Jagung Tipe Bak Datar Model Segiempat dan Silinder. Jurnal Enjiniring Pertanian, Balai Besar Pengembangan Mekanisasi Pertanian. 